\title{
STUDY ON WATER QUALITY OF HINDON RIVER (TRIBUTARY OF YAMUNA RIVER)
}

\author{
Deepak Kumar ${ }^{1, *}$, Vinay Kumar ${ }^{2}$ and Sangeeta Kumari ${ }^{3}$ \\ ${ }^{1}$ Amity Institute of Biotechnology, Amity University, 122143, Gurgaon Haryana, India \\ ${ }^{2}$ Chemical Section, Intertek India Pvt. Ltd., 122016, Gurgaon Haryana, India \\ ${ }^{3}$ Amity Institute of Biotechnology, Amity University, 122143, Gurgaon Haryana, India \\ *E-mail : deepak.biotech@hotmail.com
}

\begin{abstract}
Hindon River has become a destination for a dump of untreated industrial and domestic waste that attributes to the deterioration of water quality. In this study, Samples were collected from five sites between Muzaffarnagar and Meerut along the Hindon River during July 2016-June 2017 to evaluate the seasonal variation of water quality. These water samples were analyzed for $\mathrm{pH}$, Electrical conductivity (EC), Dissolved oxygen (DO), Chemical oxygen demand (COD), Biological oxygen demand (BOD),Total dissolved solids (TDS), Total suspended solids (TSS), Total hardness $(\mathrm{TH})$, Total Alkalinity (TA), Nitrate $\left(\mathrm{NO}_{3}{ }^{-}\right)$, Sulphate $\left(\mathrm{SO}_{4}^{-2}\right)$, Sodium $\left(\mathrm{Na}^{+}\right)$, Calcium $\left(\mathrm{Ca}^{2+}\right)$ and Magnesium $\left(\mathrm{Mg}^{2+}\right)$ and the status of water quality was determined by using water quality index (WQI).The results revealed that all physicochemical parameters were beyond the prescribed limit by BIS standard (IS 10500) and the water quality was most deteriorated during pre-monsoon season as compared to monsoon and post-monsoon season. Therefore, based on this study, it can be believed that Hindon river water is not acceptable drinking, fish farming and irrigation activities at all the sampling sites along the Hindon River.
\end{abstract}

Keywords: WQI, Drinking Water Quality Index, Hindon River, Physicochemical parameters.

(C) RASĀYAN. All rights reserved

\section{INTRODUCTION}

A river comprises of both the main course and the tributaries, brings substantial contents in form of dissolved and minute separate particles from both natural and anthropogenic sources. It is the foundations of many civilizations and is responsible for supporting and maintaining various forms of life. Unfortunately, rivers play a major role in accommodation or transportation of industrial wastewater, municipal waste and runoff from agricultural land and most of the times, rivers are considered as places for disposal of the sewage ${ }^{1}$. Municipal and industrial wastewater discharge constitutes a constant polluting source, whereas surface runoff is a seasonal phenomenon, largely affected by climate within the basin $^{2}$. However, urbanization has a direct influence on water resources through the settlement around the locality of water bodies by encroachment ${ }^{3}$ and associated industrial development which has exerted tremendous burden on this vital resource leading to the deterioration of water quality ${ }^{4}$. Hindon River is the main tributary of Yamuna River, one of the major rivers of India, is confronted with the serious threat for its existence mainly because of various anthropogenic activities including disposal of untreated and partially treated industrial effluents and sewage containing toxic metals ${ }^{5}$. This highly polluted river covers an extensive area and is being widely used for various purposes in domestic, agricultural and industrial activities. Besides this, lack of common policy for effluent discharge in the river and lack of approach by the government toward the restoration of rivers have made the river water unsuitable for ecological use ${ }^{6}$. Since the quality of water is directly and indirectly associated with human health and another living being, therefore, it is an essential concern for human beings. In addition to urbanization, different materials like flowers, incense sticks, food, sweets, clothes etc. used in religious rituals activities spread out in rivers which results in pollution and deterioration of river water quality and is supplied as potable water for urban population ${ }^{7}$.

Rasayan J. Chem., 11(4), 1477-1484(2018)

http://dx.doi.org/10.31788/RJC.2018.1143075

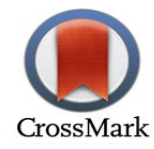


The polluted water can cause an adverse effect on plant growth and human health, therefore, the water pollution has become an imperative subject to be prevented and controlled worldwide ${ }^{8}$. Water quality index (WQI) which is a mathematical model, transforms several physicochemical parameters of waters into a single number and represents the level of water quality. The concept of water quality to categorize water according to its degree of purity or pollution pertains to 1848 in Germany ${ }^{9}$.

\section{Study Area and Sample Collection}

\section{EXPERIMENTAL}

Water samples were collected during periods July 2016 to June 2017 from five sampling locations viz. Atali village (S-1), Baparsi village (S-2), Shekhpura village (S-3), Kalina village (S-4), Kinauni village (S-5) of which details are shown in Table 1, These were collected into new polyethylene bottles that had been rinsed two to three times with the water to be analyzed. The bottles were filled until overflowing and closed underwater to minimize aeration. All bottles were carefully labeled and numbered prior to transport and kept at low temperature $4{ }^{\circ} \mathrm{C}$ and then received samples were analyzed for different physicochemical parameters (as described in Table 5) by following the standard methods of APHA (2012).

Most commonly used water quality parameters namely $\mathrm{pH}$ (by $\mathrm{pH}$ meter), EC (by electrical conductivity meter), TDS and TSS (by gravimetric method), TA, TH, DO, COD, BOD, $\mathrm{Ca}^{2+}$ and $\mathrm{Mg}^{2+}$ (by titrimetric method), $\mathrm{SO}_{4}{ }^{2-}$ and $\mathrm{NO}_{3}^{-}$(by UV/VIS spectrophotometer), and $\mathrm{Na}^{+}$(Atomic absorption spectroscopy), together, reflect the overall water quality of the Hindon River and were selected for generating the water quality index (WQI).

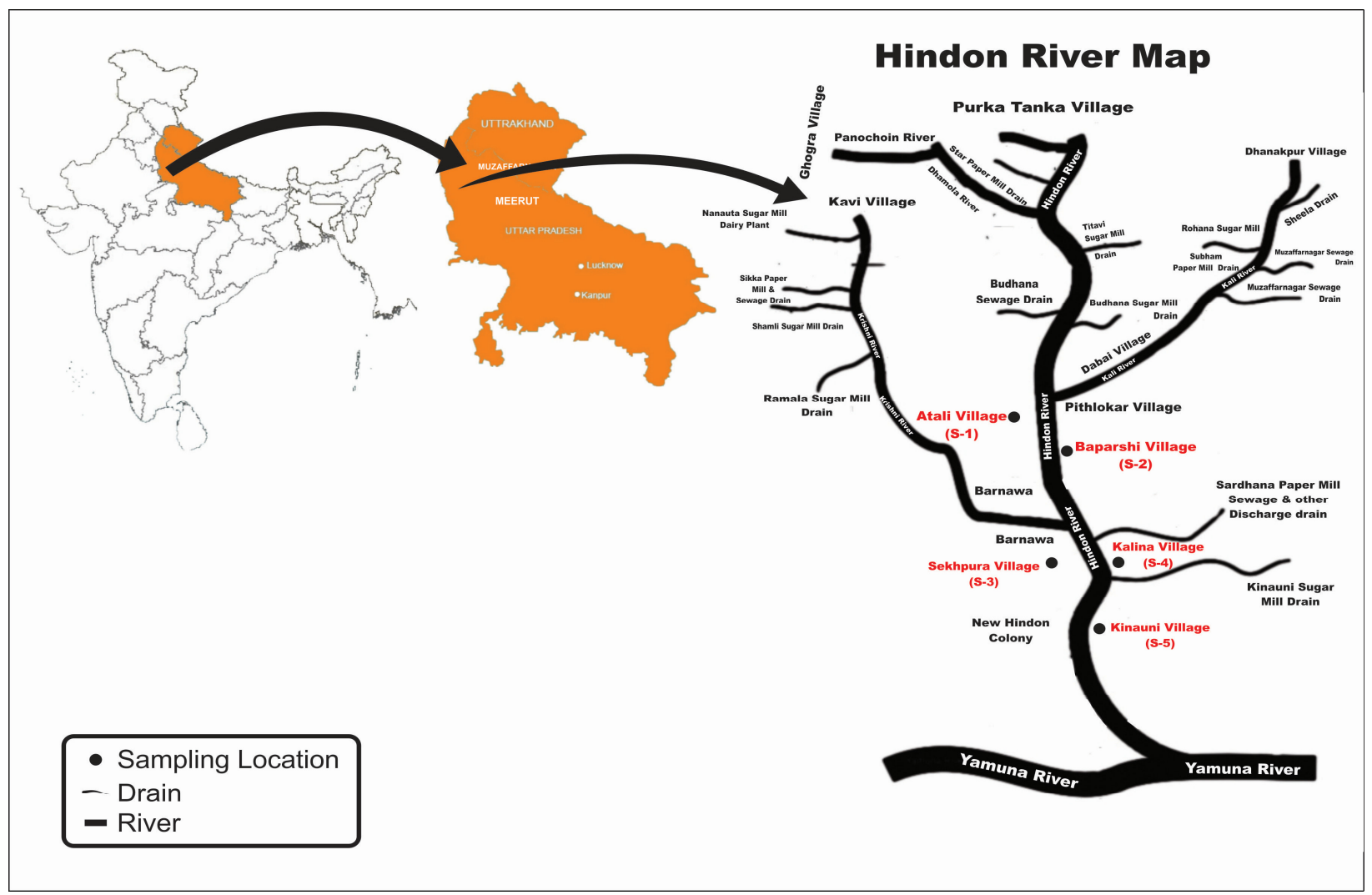

Fig.-1: Sampling Locations in Map of Hindon River

\section{Water Quality Index Determination}

Water quality index (WQI) is defined as a technique of rating that provides the composite influence of individual water quality parameter on the overall quality of water ${ }^{10}$. WQI has been calculated to evaluate the suitability of water quality of Hindon River using the weighted arithmetic water quality 
index method, which classifies the water quality according to the degree of purity by using the most commonly, measured water quality variables. Calculation of WQI was carried out by following the 'weighted arithmetic index method as stated below'

$$
\mathrm{WQI}=\sum \mathrm{Q}_{\mathrm{n}} \mathrm{W}_{\mathrm{n}} / \sum \mathrm{W}_{\mathrm{n}}
$$

Where, $Q_{n}$ is the quality rating of the $n^{\text {th }}$ water quality parameter, $W_{n}$ is the unit weight of $n^{\text {th }}$ water quality parameter.

The quality rating $Q_{n}$ is calculated using the equation:

$$
\mathrm{Q}_{\mathrm{n}}=100\left[\left(\mathrm{~V}_{\mathrm{n}}-\mathrm{V}_{\mathrm{i}}\right) /\left(\mathrm{V}_{\mathrm{s}}-\mathrm{V}_{\mathrm{i}}\right)\right]
$$

Where, $V_{n}$ is the actual amount of $n^{\text {th }}$ parameter present, $V_{i}$ is the ideal value of the parameter $\left[V_{i}=0\right.$, except for $\mathrm{pH}\left(V_{i}=7\right)$ and $\left.\mathrm{DO}\left(V_{i}=14.6 \mathrm{mg} / \mathrm{l}\right)\right], V_{s}$ is the standard permissible value for the $n^{\text {th }}$ water quality parameter.

Unit weight $\left(W_{n}\right)$ is calculated using the formula:

$$
\mathrm{W}_{\mathrm{n}}=\mathrm{k} / \mathrm{V}_{\mathrm{s}}
$$

Where, $k$ is the constant of proportionality and it is calculated using the equation:

$$
\mathrm{k}=\left[1 / \sum 1 / \mathrm{V}_{\mathrm{s}}=1,2, \ldots, \mathrm{n}\right]
$$

\begin{tabular}{|c|c|c|c|c|}
\hline S. No. & $\begin{array}{c}\text { Sampling } \\
\text { Location Code }\end{array}$ & Names of Area & Location & Description \\
\hline 1 & S-1 & Atali Village & $\begin{array}{l}29^{\circ} 12^{\prime} 43.4^{\prime \prime} \mathrm{N} \\
77^{\circ} 31^{\prime} 18.4^{\prime \prime} \mathrm{E}\end{array}$ & $\begin{array}{l}\text { This site is the confluence of Kali River and } \\
\text { Hindon River, near to Budhhana } 4 \text { km away }\end{array}$ \\
\hline 2 & S-2 & $\begin{array}{l}\text { Baparsi } \\
\text { Village }\end{array}$ & $\begin{array}{l}29^{\circ} 11^{\prime} 07.2^{\prime \prime} \mathrm{N} \\
77^{\circ} 29^{\prime} 42.6^{\prime \prime} \mathrm{E}\end{array}$ & $\begin{array}{l}\text { This site brings a load of agriculture run off } \\
\text { and small industrial effluents. }\end{array}$ \\
\hline 3 & S-3 & $\begin{array}{l}\text { ShekhpuraVill } \\
\text { age }\end{array}$ & $\begin{array}{l}29^{\circ} 05^{\prime} 34.4^{\prime \prime} \mathrm{N} \\
77^{\circ} 25^{\prime} 21.1^{\prime \prime} \mathrm{E}\end{array}$ & $\begin{array}{l}\text { This site is the merging point of Krishna } \\
\text { River }\end{array}$ \\
\hline 4 & S-4 & Kalina Village & $\begin{array}{l}29^{\circ} 04^{\prime} 27.1^{\prime \prime N} \\
77^{\circ} 27^{\prime} 43.6^{\prime \prime} \mathrm{E}\end{array}$ & $\begin{array}{l}\text { It has the major polluting drain from } \\
\text { Sardhana. }\end{array}$ \\
\hline 5 & S-5 & $\begin{array}{l}\text { Kinauni } \\
\text { Village }\end{array}$ & $\begin{array}{l}29^{\circ} 03^{\prime} 05.2^{\prime \prime} \mathrm{N} \\
77^{\circ} 27^{\prime} 15.9^{\prime \prime} \mathrm{E}\end{array}$ & $\begin{array}{l}\text { It is the point of having a high amount of } \\
\text { pollution from industries. }\end{array}$ \\
\hline
\end{tabular}

The water quality status (WQS) according to WQI is shown in Table-2.

Table-1: Sampling Location along Hindon River

\section{Physico-Chemical Properties}

\section{RESULTS AND DISCUSSION}

pH ranged from 6.44 to 7.91. Each sampling location has almost the same pH. Sampling location (S-4) denoted low $\mathrm{pH}$ (6.4).IS 10500 recommended the $\mathrm{pH}$ value from 6.5 to 8.5 for drinking purpose, therefore, $\mathrm{pH}$ of five sampling location reached the criteria of quality standard.

Electrical conductivity, which measures the capacity of a water sample to carry the electric current, is directly associated with the dissolved ions existing in the water and was analyzed using a digital conductivity meter as microsiemen/centimeter. Observed EC values for the water samples of the Hindon River ranged between 1076-2122 $\mu$ S/cm.

Total suspended solids (TSS), varied from78 to $223 \mathrm{mg} / \mathrm{l}$. It relies on the weight of the residue (after the water evaporated) from materials contained in the water as a suspension. Overall water quality data of Hindon River at 5 locations is presented in Table-3. High TDS and TSS can boost the water temperature because solid materials absorb heat from sunlight. Since when the rain falls, dilution occurs in river water and decreases the TSS, but it can also increase TSS depending on the watershed. CPCB standard prescribes TSS $<100 \mathrm{mg} / \mathrm{l}$, therefore TSS of five sampling location did not meet the quality standard. The range of TDS falls between $\mathbf{9 2 3 - 1 3 4 2} \mathrm{mg} / \mathrm{l}$. IS 10500 recommends the TDS <500 mg/l, hence TDS of all five locations was found out of the standard permissible value. TDS is determined for measuring the amount of solid materials dissolved in the water (surface, ground). High TDS value causes harmful effect 
RASĀYAN J. Chem.

Vol. 11 | No. 4 |1477 - 1484| October - December | 2018

to the public health such as the central nervous system, irritability, dizziness, provoking paralysis of the tongue, lips andface ${ }^{13}$.

Table-2: WQI Range, Status and possible usage of the Water Sample ${ }^{12}$

\begin{tabular}{c|c|c}
\hline WQI & $\begin{array}{c}\text { Water quality status } \\
\text { (WQS) }\end{array}$ & Possible usage \\
\hline $0-25$ & Excellent & $\begin{array}{c}\text { Drinking, irrigation and } \\
\text { industrial }\end{array}$ \\
\hline $26-50$ & Good & $\begin{array}{c}\text { Drinking, irrigation and } \\
\text { industrial }\end{array}$ \\
\hline $51-75$ & Poor & Irrigation and industrial \\
\hline $76-100$ & Very poor & Irrigation \\
\hline Above 100 & $\begin{array}{c}\text { Unsuitable for drinking } \\
\text { and fish culture }\end{array}$ & $\begin{array}{c}\text { Proper treatment } \\
\text { required before use }\end{array}$ \\
\hline
\end{tabular}

Total Alkalinity (TA) and Total Hardness (TH)

The alkalinity of the water body is a measure of its capacity to neutralize acid to a designated $\mathrm{pH}$. The maximum value i.e. $432 \mathrm{mg} / \mathrm{l}$ was found at sampling location $\mathrm{S}-1$ during the pre-monsoon. The high alkalinity may be due to the concentration of domestic sewage and consumption of fertilizers in agriculture. For drinking use, desirable alkalinity is less than $200 \mathrm{ppm}$ as per IS 10500. At all sampling locations, alkalinity crossed the standard permissible value. Total hardness of water increases the boiling point and reduces the formation of lather. During the study period, total hardness was found between 273-551 mg/l, which was out of prescribed limit i.e. $200 \mathrm{mg} / \mathrm{l}$ as per IS 10500.

\section{Dissolved Oxygen (DO)}

DO is the concentration of oxygen dissolved in the water. Its presence is essential to maintain a variety of biological life forms in water and the effect of a waste discharge in a water body is largely determined by the oxygen balance of the system ${ }^{14}$. Natural water bodies have high levels of oxygen which varies depending on temperature, salinity, water turbulence, and atmospheric pressure ${ }^{13}$. DO values ranged between 0.8-5.1 mg/l. All five sampling locations had almost the same DO and still not in good criteria. DO is necessary for the survival of aquatic organisms. The low DO indicates high demand for oxygen by the microorganisms. The more organic materials that pollute the water body, the more amount of oxygen consumed to decompose these materials, therefore, the content of dissolved oxygen in the water decreases so low. As per CPCB (class A), DO must be less than $6 \mathrm{mg} / \mathrm{l}$, hence the DO of the all sampling location was out of the standard permissible value.

\section{Biochemical Oxygen Demand (BOD) and Chemical Oxygen Demand (COD)}

Biochemical Oxygen Demand (BOD) is a measure of the amount of oxygen used by microorganisms to decompose organic materials in water within five days period. The high BOD value indicates the high organic pollution $^{13}$. The BOD in Hindon river ranging 74-141 mg/l was relatively high. This might be due to the decomposition process of organic matter by microorganisms consuming oxygen. High BOD in water is undesirable because it will reduce the DO. As per CPCB (class A), BOD must be $<3 \mathrm{mg} / \mathrm{l}$, therefore BOD of all five sampling locations did not meet the criteria of the standard permissible value. The COD ranged between 232-532 mg/l. COD in each sampling location was not much different,but exceeded the standard permissible value. This was likely caused by decomposition of organic matter in the form of leaves, trunks etc. that consumed much oxygen. High oxygen consumption in the chemical process shows increased pollution in water bodies. 
RASĀYAN $J$. Chem.

Vol. 11 | No. 4 |1477 - 1484| October - December | 2018

Calcium, Magnesium, Sodium, Sulphate and Nitrate

Both calcium and magnesium are essential minerals and beneficial to human health in several aspects. Inadequate intake of either nutrient can result in adverse health consequences (WHO standard). As per IS 10500 , limits for calcium and magnesium content are $\leq 75 \mathrm{mg} / \mathrm{l}$ and $\leq 30 \mathrm{mg} / \mathrm{l}$ respectively, where the concentration of $\mathrm{Ca}$ and $\mathrm{Mg}$ at five sampling locations ranged from 94-136 mg/l and 16-52 mg/l respectively which were found out of standard permissible value for drinking purpose. Nitrate concentration on five sampling locations ranging from $2.9-5.1 \mathrm{mg} / \mathrm{l}$ was relatively low. This is highly related to the small number of human activities nearby ${ }^{15-17}$. A major source of river water pollution comes from domestic sewage, small industries, animal waste, agricultural waste, soil erosion and runoff from the settlement. As per IS 10500 , nitrate content has to be $\leq 45 \mathrm{mg} / \mathrm{l}$, therefore nitrate at five sampling location was within the quality standard. The sulphate concentration ranged between $39-59 \mathrm{mg} / \mathrm{l}$ which is under the permissible limit of $200 \mathrm{mg} / \mathrm{l}$ as per IS 10500 . The concentration of sodium was found between 10-32 $\mathrm{mg} / \mathrm{l}$, there is no as such specification for sodium, but a high concentration of sodium could cause an unpleasant taste.

Table-3: Analytical Results of Physico-Chemical Parameters in the River Water from July 2016 to June 2017

\begin{tabular}{|c|c|c|c|c|c|c|c|c|c|c|}
\hline \multicolumn{2}{|c|}{$\begin{array}{l}\text { Sampling } \\
\text { location }\end{array}$} & $\mathrm{pH}$ & $\begin{array}{c}\mathrm{EC} \\
(\mu \mathrm{S} / \mathrm{cm})\end{array}$ & $\begin{array}{c}\text { TDS } \\
(\mathrm{mg} / \mathrm{l})\end{array}$ & $\begin{array}{c}\text { TSS } \\
(\mathrm{mg} / \mathrm{l})\end{array}$ & $\begin{array}{c}\mathrm{TA} \\
(\mathrm{mg} / \mathrm{l}) \\
\end{array}$ & $\begin{array}{c}\mathrm{TH} \\
(\mathrm{mg} / \mathrm{l}) \\
\end{array}$ & $\begin{array}{c}\mathrm{DO} \\
(\mathrm{mg} / \mathrm{l}) \\
\end{array}$ & $\begin{array}{l}\text { COD } \\
(\mathrm{mg} / \mathrm{l}) \\
\end{array}$ & $\begin{array}{r}\text { BOD } \\
(\mathrm{mg} / \mathrm{l}) \\
\end{array}$ \\
\hline \multirow[t]{3}{*}{ S-1 } & PEM & 7.12 & 1583 & 1342 & 234 & 432 & 448 & 0.8 & 532 & 132 \\
\hline & $\mathrm{M}$ & 7.16 & 1343 & 1175 & 162 & 382 & 360 & 3.1 & 344 & 96 \\
\hline & POM & 7.34 & 1632 & 1254 & 138 & 408 & 461 & 1.2 & 357 & 105 \\
\hline \multirow{3}{*}{ S-2 } & PEM & 7.15 & 1193 & 984 & 124 & 399 & 387 & 0.9 & 311 & 110 \\
\hline & $\mathrm{M}$ & 6.61 & 1762 & 1029 & 88 & 416 & 436 & 3.2 & 311 & 85 \\
\hline & POM & 7.19 & 1319 & 1156 & 96 & 432 & 468 & 1.8 & 287 & 98 \\
\hline \multirow[t]{3}{*}{ S-3 } & PEM & 7.57 & 1863 & 1143 & 216 & 457 & 390 & 1.1 & 289 & 108 \\
\hline & $\mathrm{M}$ & 6.92 & 1935 & 1570 & 98 & 398 & 393 & 3.3 & 254 & 103 \\
\hline & POM & 7.74 & 1238 & 1167 & 126 & 410 & 467 & 2.2 & 274 & 141 \\
\hline \multirow[t]{3}{*}{ S-4 } & PEM & 7.26 & 1351 & 1073 & 134 & 406 & 403 & 1.1 & 301 & 138 \\
\hline & $M$ & 7.32 & 1402 & 1148 & 77 & 397 & 273 & 2.8 & 276 & 98 \\
\hline & POM & 6.44 & 1076 & 923 & 96 & 426 & 404 & 1.1 & 285 & 117 \\
\hline \multirow[t]{3}{*}{ S-5 } & PEM & 7.86 & 1748 & 1414 & 84 & 387 & 483 & 1.6 & 243 & 111 \\
\hline & $\mathrm{M}$ & 7.52 & 1452 & 1189 & 78 & 399 & 551 & 5.1 & 232 & 74 \\
\hline & POM & 7.91 & 2122 & 1352 & 92 & 405 & 441 & 3.8 & 264 & 107 \\
\hline
\end{tabular}

PEM (Pre-Monsoon), M (Monsoon) and POM (Post-Monsoon)

Table-4: Analytical Results of Ion Concentration in the River Water from July 2016 to June 2017

\begin{tabular}{c|c|c|c|c|c|c}
\hline \multicolumn{2}{c|}{$\begin{array}{c}\text { Sampling } \\
\text { location }\end{array}$} & $\begin{array}{c}\mathrm{Ca}^{2+} \\
(\mathrm{mg} / \mathrm{L})\end{array}$ & $\begin{array}{c}\mathrm{Mg}^{2+} \\
(\mathrm{mg} / \mathrm{L})\end{array}$ & $\begin{array}{c}\mathrm{Na}^{+} \\
(\mathrm{mg} / \mathrm{L})\end{array}$ & $\begin{array}{c}\mathrm{SO}_{4}{ }^{-} \\
(\mathrm{mg} / \mathrm{L})\end{array}$ & $\begin{array}{c}\mathrm{NO}_{3}{ }^{-} \\
(\mathrm{mg} / \mathrm{L})\end{array}$ \\
\hline S-1 & PEM & 120 & 36 & 28 & 59 & 3.5 \\
\hline & M & 98 & 28 & 24 & 53 & 3.9 \\
\hline & POM & 112 & 44 & 32 & 47 & 2.9 \\
\hline S-2 & PEM & 94 & 37 & 22 & 49 & 4.5 \\
\hline & M & 102 & 44 & 19 & 48 & 5.1 \\
\hline & POM & 128 & 36 & 18 & 52 & 4.7 \\
\hline S-3 & PEM & 110 & 28 & 16 & 47 & 3.8 \\
\hline & M & 118 & 24 & 18 & 53 & 3.7 \\
\hline S-4 & POM & 136 & 31 & 17 & 49 & 4.1 \\
\hline & PEM & 97 & 39 & 12 & 38 & 3.4 \\
\hline & POM & 93 & 16 & 10 & 43 & 3.6 \\
\hline S-5 & PEM & 116 & 47 & 11 & 47 & 4.8 \\
\hline & M & 135 & 52 & 10 & 39 & 4.5 \\
\hline & POM & 114 & 38 & 12 & 43 & 4.9 \\
\hline
\end{tabular}

1481 
RASĀYAN J. Chem.

Vol. 11 | No. 4 |1477 - 1484| October - December | 2018

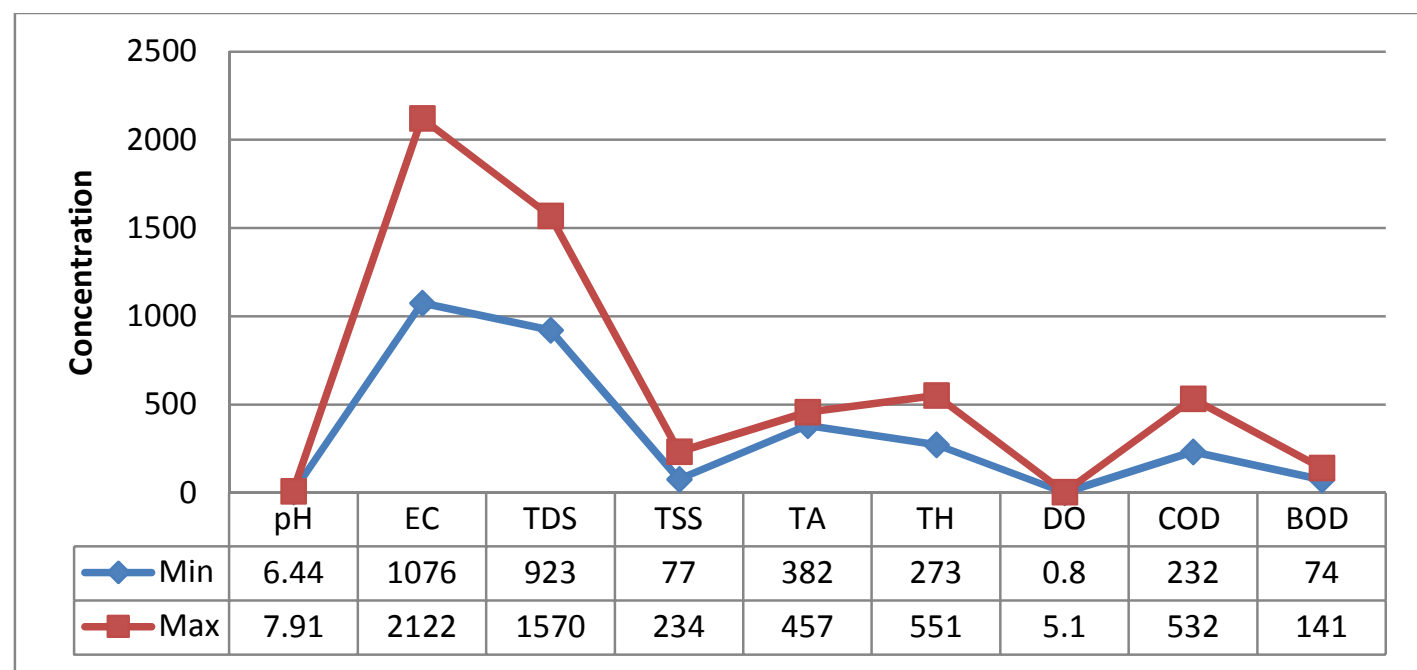

Fig.-2: Trend of Physicochemical parameters in River Water (July 2016-June 2017)

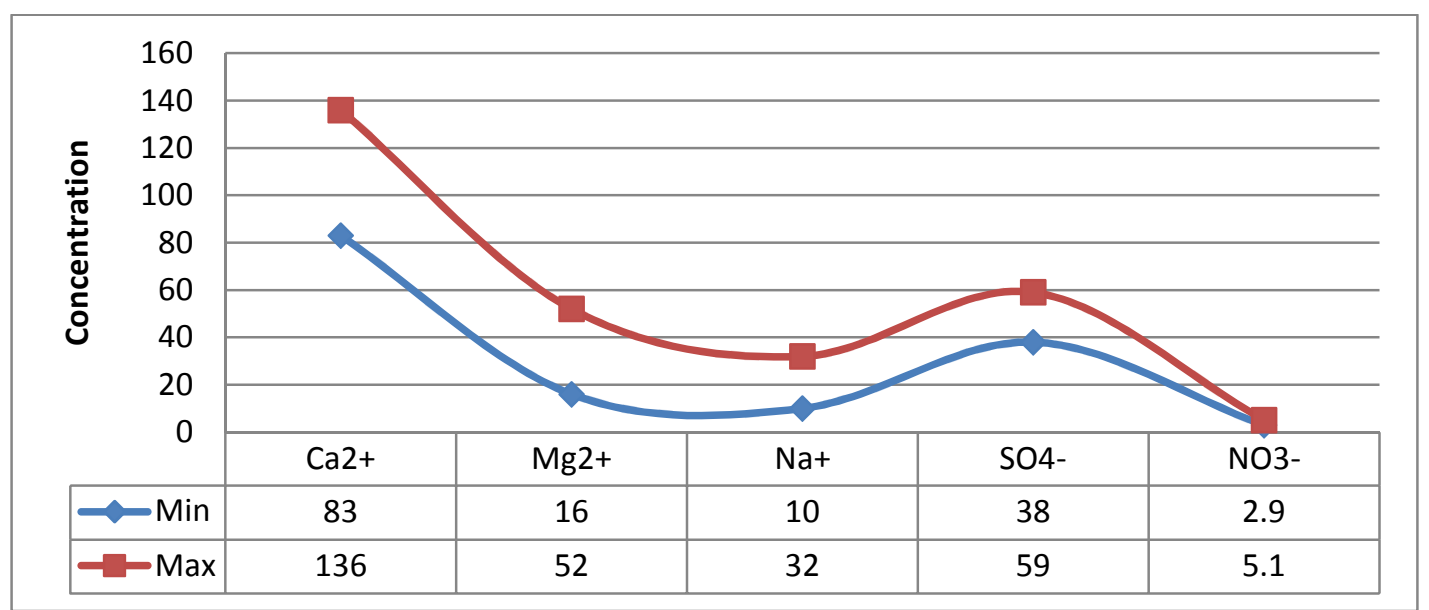

Fig.-3: Trend of Ion Concentration in River Water (July 2016-June 2017)

\section{Water Quality Index}

In the first step for WQI of river water, the quality rating of each parameter is calculated with the formula: $\mathrm{Q}_{\mathrm{n}}=100 *\left[\left(\mathrm{~V}_{\mathrm{n}}-\mathrm{V}_{\mathrm{i}}\right) /\left(\mathrm{V}_{\mathrm{s}^{-}} \mathrm{V}_{\mathrm{i}}\right)\right]$. If quality rating $\mathrm{Q}_{\mathrm{n}}=0$ implies the complete absence of pollutants, while 0 $<\mathrm{Q}_{\mathrm{n}}<100$ means the pollutants are within the prescribed standard and when $\mathrm{Q}_{\mathrm{n}}>100$, it indicates that the pollutants are above the standards. In the second step, the unit weight $\left(\mathrm{W}_{\mathrm{n}}\right)$ which is assigned to all the physicochemical parameters (i.e. pH, TDS, TSS, TA, TH, DO, BOD, Calcium, Magnesium, Sulphate and Nitrate) is calculated using the formula: $\mathrm{W}_{\mathrm{n}}=\mathrm{k} / \mathrm{V}_{\mathrm{n}}$. These unit-weights transform all the concerned parameters of different units and dimensions to a common scale. Table 5 shows the drinking water quality standards and the unit weights assigned to each parameter used for calculating the WQI. Unit weight of DO and BOD i.e., 0.234 and 0.467 respectively had significance and impact in water quality assessment. Water Quality Index reveals water quality on many levels that affect host life and a potential peril to various uses of water.

In this study, calculated WQI value ranged from 1369 to 2199 for all locations in all seasons and unveiled that water quality of Hindon River deteriorated at all location and was unsuitable (Bad)for purposes like drinking, fish farming and irrigation. The water quality was found to be most deteriorated during premonsoon season as compared to monsoon and post-monsoon season. The unsuitability of water was attributed by increasing industrial activities and domestic sewage disposal. In Table 3, 4 and 6, Physicochemical parameter values and WQI score clearly showed the contribution of untreated waste from industries and small-scale factories, domestic waste, Kali River and Krishni River for pollution of all Hindon River. 
RASĀYAN J. Chem.

Vol. 11 | No. 4 | 1477 - 1484| October - December | 2018

Table-5: The Unit Weight of each of the Physicochemical Parameters used for WQI Determination

\begin{tabular}{c|c|c}
\hline Parameters & $\begin{array}{c}\text { CPCB*/BIS Standard } \\
(\text { IS 10500) }\end{array}$ & $\begin{array}{c}\text { Unit Weight } \\
\left(\mathrm{W}_{\mathrm{n})}\right.\end{array}$ \\
\hline $\mathrm{pH}$ & $6.5-8.5$ & 0.165 \\
\hline $\mathrm{EC}$ & - & - \\
\hline TDS & 500 & 0.003 \\
\hline TSS* & 100 & 0.014 \\
\hline Total Alkalinity & 200 & 0.007 \\
\hline Total Hardness & 200 & 0.007 \\
\hline DO* & 6 & 0.234 \\
\hline BOD* & 3 & 0.467 \\
\hline COD & - & - \\
\hline Calcium & 75 & 0.019 \\
\hline Magnesium & 30 & 0.047 \\
\hline Sodium & - & 0.007 \\
\hline Sulphate & 200 & 0.031 \\
\hline Nitrate & 45 & \\
\hline
\end{tabular}

Table-6: Summary of WQI of the Hindon River

\begin{tabular}{c|c|c|c|c|c|c}
\hline \multirow{2}{*}{$\begin{array}{c}\text { Sampling } \\
\text { Location }\end{array}$} & \multicolumn{2}{|c|}{ Pre-Monsoon } & \multicolumn{2}{c|}{ Monsoon } & \multicolumn{2}{c}{ Post-Monsoon } \\
\cline { 2 - 7 } & WQI & wQS & WQI & wQS & WQI & WQS \\
\hline SL1 & 2108 & Unsuitable & 1538 & Unsuitable & 1687 & Unsuitable \\
\hline SL2 & 1763 & Unsuitable & 1369 & Unsuitable & 1575 & Unsuitable \\
\hline SL3 & 2043 & Unsuitable & 1646 & Unsuitable & 1732 & Unsuitable \\
\hline SL4 & 2199 & Unsuitable & 1567 & Unsuitable & 1872 & Unsuitable \\
\hline SL5 & 1779 & Unsuitable & 1195 & Unsuitable & 1709 & Unsuitable \\
\hline Average & 1978.57 & & 1462.94 & & 1714.84 & \\
\hline
\end{tabular}

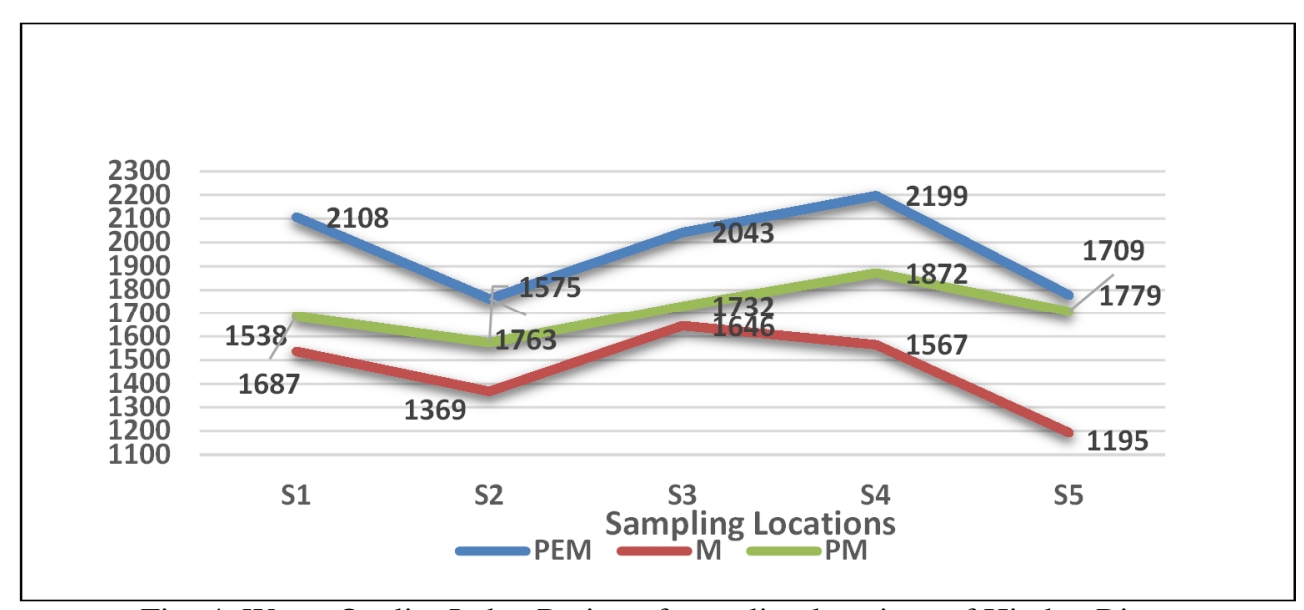

Fig.-4: Water Quality Index Rating of sampling locations of Hindon River

\section{CONCLUSION}

The present study gives insight for 12 months during (July 2016-June 2017) of the Hindon River water based on WQI values which determine the overall quality of river water. According to the criteria of water quality, this river can be categorized as being extremely polluted and effective treatment measures are urgently required to enhance the river water quality by defining a sustainable water quality management plan for river restoration. The high WQI values in river water were mostly just because of the presence of major harmful toxic chemical elements and nutrients beyond their permissible limits, which directly indirectly affects the flora and fauna of the aquatic system as well as human population. 
Pollution level acceleration generally causes greater deterioration of the ecological system. To recover the water quality of the Hindon River, treatment of various effluents before discharged directly and indirectly into Hindon water is required.

\section{ACKNOWLEDGMENT}

The author thanks the faculty of Amity University, Gurgaon for continuous support and Intertek India Pvt. Ltd. Gurgaon for its facilities to complete my research work.

\section{REFERENCES}

1. M. Benedini and G. Tsakiris, Water Quality Modelling for Rivers and Streams, Springer, Netherlands, p.1-9 (2013), DOI: 10.1007/978-94-007-5509-3

2. M.K. Sharma, C.K. Jain and O. Singh, J. Indian Water Res. Soc. 34 (1), 53 (2014).

3. R. Arora, H. C. Joshi, I. P. Pandey and V. K. Tewari, Rasayan J. Chem., 10(4), 1167(2017), DOI: 10.7324/RJC.2017.1041753

4. A. Sood, K.D. Singh, P. Pandey and S. Sharma, Ecological Indicator, 8(5), 709 (2008), DOI: 10.1016/j.ecolind.2008.01.001

5. R. Reza, G. Singh, International Journal of Environmental Science and Technology, 7(4), 785(2010), DOI: $10.1007 / \mathrm{BF} 03326187$

6. R. Bhardwaj, A. Gupta, J. K. Garg, India, National Water Research Center, 31(1), 52 (2017), DOI: 10.1016/j.wsj.2017.02.002.

7. K. P. Singh, D. Mohan, V. K. Singh, A. Malik, Journal of Hydrology, 312, 14 (2005), DOI: 10.1016/j.jhydrol.2005.01.021

8. K. P. Singh, A. Malik, D. Mohan and S. Sinha, Water Research, 38(18), 3980 (2004), DOI: 10.1016/j.watres.2004.06.011

9. R. K. Horton, J. Water Poll. Control Federation, 37(3), 300(1965).

10. M. Guettaf, A. Maoui and Z. Ihdene, Appl. Water Sci., 7(1), 295 (2017), DOI: 10.1007/s13201-0140245-z

11. R. M. Brown, NI. McClelland, R. A. Deininger and R. G. Tozer, Water and Sewage Works, p.339343 (1970).

12. R. M. Brown, NI. McClelland, R.A. Deininger and M.F. O'Connor, Indicators of Environmental Quality, p.173-182 (1972).

13. N. Gupta, P. Pandey and J. Hussain, Water Science, 31(1), 11(2017), DOI: 10.1016/j.wsj.2017.03.002

14. H. Chang, Water Air Soil Pollut. 161 (4), 267 (2005), DOI: 10.1007/s11270-005-4286-7

15. B. Nas and A. Berktay, Journal of Environmental Management, 79(1), 30(2006), DOI: 10.1016/j.jenvman.2005.05.010

16. W. Duan, K. Takara, B. He, P. Luo, D. Nover and Y. Yamashiki, Sci. Total Environ. 461, 499 (2013) DOI: $10.1016 /$ j.scitotenv.2013.05.022

17. R. K. Yadav and M.R. Augur, Rasayan J. Chem., 11(2), 537(2018), DOI: 10.31788/RJC.2018.1122089

18. APHA Standard Methods for Examination of Water and Wastewater, 22 ${ }^{\text {nd }}$ edn. American Public Health Association, Washington (2012).

19. Central Pollution Control Board (CPCB), Report on Status of Quality in India. Central Pollution Control Board, Monitoring of Indian National Aquatic, Resources, (2011).

20. Indian Standard Specification for Drinking Water, Bureau of Indian Standards, BIS: 10500, 2012.

21. WHO Guidelines for drinking-water quality, World Health Organization, Vol.1, 3rd Edn., WHO, Geneva Recommendation (2004).

[RJC-3075/2018] 